\title{
Stable genetic diversity despite parasite and pathogen spread in honey bee colonies
}

\author{
Laura Jara ${ }^{1}$ - Irene Muñoz ${ }^{2}$ - Almudena Cepero ${ }^{3}$ - Raquel Martín-Hernández ${ }^{3,4}$. \\ José Serrano $^{1}$ • Mariano Higes ${ }^{3} \cdot$ Pilar De la Rúa ${ }^{1}$
}

Received: 19 May 2015 /Revised: 26 June 2015 / Accepted: 31 July 2015 / Published online: 26 August 2015

(C) Springer-Verlag Berlin Heidelberg 2015

\begin{abstract}
In the last decades, the rapid spread of diseases, such as varroosis and nosemosis, associated with massive honey bee colonies mortality around the world has significantly decreased the number and size of honey bee populations and possibly their genetic diversity. Here, we compare the genetic diversity of Iberian honey bee colonies in two samplings performed in 2006 and 2010 in relation to the presence of the pathogenic agents Nosema apis, Nosema ceranae, and Varroa destructor in order to determine whether parasite and pathogen spread in honey bee colonies reflects changes in genetic diversity. We found that the genetic diversity remained similar, while the incidence of $N$. ceranae increased and the incidence of $N$. apis and $V$. destructor decreased slightly. These results indicate that the genetic diversity was not affected by the presence of these pathogenic agents in the analyzed
\end{abstract}

Communicated by: Sven Thatje

Electronic supplementary material The online version of this article (doi:10.1007/s00114-015-1298-z) contains supplementary material, which is available to authorized users.

Pilar De la Rúa

pdelarua@um.es

1 Departamento de Zoología y Antropología Física, Facultad de Veterinaria, Universidad de Murcia, 30100 Murcia, Spain

2 Mountain Research Centre (CIMO), Polytechnic Institute of Bragança, Campus de Sta. Apolónia, Apartado 1172, 5301-855 Bragança, Portugal

3 Centro Apícola Regional (CAR), Dirección General de la Producción Agropecuaria, Consejería de Agricultura, Junta de Comunidades de Castilla-La Mancha, 19180 Marchamalo, Spain

4 Instituto de Recursos Humanos para la Ciencia y la Tecnología (INCRECYT), Fundación Parque Científico y Tecnológico de Albacete, Albacete, Spain period. However, the two groups of colonies with and without Nosema/Varroa detected showed significant genetic differentiation ( $\mathrm{G}$ test). A detailed analysis of the allelic segregation of microsatellite loci in Nosema/Varroa-negative colonies and parasitized ones revealed two outlier loci related to genes involved in immune response.

Keywords Heterozygosity · Disease $\cdot$ Selection $\cdot$ Genotyping $\cdot$ Colony losses

\section{Introduction}

The International Union for Conservation of Nature (IUCN) recognizes genetic diversity as one of the three forms of biodiversity worthy of conservation (McNeely et al. 1990). Indeed, the need to conserve genetic diversity within populations is based on two arguments: the importance of genetic variability for evolution to occur and the tight relationship between heterozygosity and population fitness (Reed and Frankham 2003). In the case of honey bees, within-colony genetic diversity has proven to reduce the negative impacts of pathogens and parasites (Crozier and Page 1985; Palmer and Oldroyd 2000; Crozier and Fjerdingstad 2001; Oldroyd and Fewell 2007). Meanwhile, the increased adaptive capacity associated with wider genetic diversity at the population level allows short-term environmental perturbations to be withstood, such as the emergence of new diseases, enabling bee populations to evolve and adapt to long-term environmental changes (Frankham et al. 2010).

Human management often brings profound changes in the genetic variation of species, and accordingly, the effect of domestication on the genetic diversity of honey bee populations has recently been addressed (Harpur et al. 2012; De la Rúa et al. 2013). In contrast to other livestock species, honey 
bees are not fully domesticated (Oxley and Oldroyd 2010) given the lack of control that beekeepers have on the natural mating of honey bee queens with unselected drones during the breeding season. Nevertheless, honey bee populations have been severely affected by human activities, and in recent decades, there has been an overall reduction in the number of colonies from different regions (Biesmeijer et al. 2006; vanEngelsdorp and Meixner 2010), potentially affecting the diversity of honey bee populations. The importation of foreign queens in an attempt to replace lost colonies has become an important driver of these changes (Muñoz et al. 2013).

Different factors have been analyzed and discussed in the literature for their potential influence on the decline and eventual disappearance of honey bee colonies. The most significant of them is possibly the increased incidence of parasites and pathogens (vanEngelsdorp et al. 2009). Particularly, virulent combinations of different pathogenic agents, instead of a single pathogenic factor, are thought to be the most likely explanation for this decline (Chen and Evans 2007; Johnson et al. 2009). Pathogens like the Varroa destructor mite (Anderson and Trueman 2000) and its associated viruses, as well as the microsporidia of the genus Nosema, are currently considered to be the most harmful pathogens of honey bees (Higes et al. 2006; Cox-Foster et al. 2007; Johnson et al. 2009; Rosenkranz et al. 2010; de Miranda and Genersch 2010; de Miranda et al. 2010), while other agents that have been around since the 1950s (American foulbrood; chalkbrood) are reported much less often nowadays.

There is accumulating evidence that genetic variation can influence host susceptibility to pathogens (Reed and Frankham 2003; Spielman et al. 2004; Whitehorn et al. 2011). However, we still have a limited and insufficient understanding of the interaction of these pathogenic organisms with their host, Apis mellifera (Martinson et al. 2011). In a recent study (Jara et al. 2012), the distribution of the $V$. destructor mite was not significantly related to that of the two evolutionary lineages making up the Iberian honey bee population, Apis mellifera iberiensis (M, Western European lineage at the North-West, and A, African lineage at the South-East; Cánovas et al. 2008). This data coincided with that obtained in the original host species of this mite, Apis cerana (Rueppell et al. 2011). However, a significantly higher incidence of the microsporidian Nosema apis was detected in northern Iberian honey bee populations belonging to the $\mathrm{M}$ lineage, a result that changed due to the rapid expansion of Nosema ceranae that now affects more than $50 \%$ of Iberian colonies (Jara et al. 2012; Martín-Hernández et al. 2012; Botías et al. 2012).

The wide dispersion of $N$. ceranae, both in Spain and worldwide (Fries 2010; Higes et al. 2010a, b; Muñoz et al. 2014), is indicative of the successful colonization of this new pathogen and the limited adaptation of its new host, A. mellifera. A potential effect of this rapid expansion of
$N$. ceranae is a reduction in genetic diversity, since invasive species may affect certain genotypes more than others, and the high risk of collapse in infected colonies (including asymptomatic colonies during the incubation period: MartínHernández et al. 2007; Higes et al. 2008). To assess the relationship between the spread of three major pathogens (N. ceranae, $N$. apis, and V. destructor), and the genetic diversity in Iberian honey bee colonies (A. mellifera iberiensis), we used microsatellite markers to analyze the genetic diversity of A. $m$. iberiensis in two different samplings obtained in 2006 and 2010. The null hypothesis tested was that changes in the frequency of pathogens and parasites are unrelated to the changes in genetic diversity of honey bee colonies. In addition, because transmissible diseases or pests are an important and universal selective evolutionary force (Seal 1991), we assessed whether any of the microsatellite alleles analyzed was associated to genes possibly involved in the adaptive response of honey bees to these harmful agents.

\section{Materials and methods}

\section{Sampling}

The samplings of this study were designed to be representative of Spanish honey bees at a country scale including samples from the peninsula and from islands such as Majorca and Tenerife. We analyzed adult worker honey bees from 228 colonies sampled in 41 Spanish provinces, corresponding to two surveys carried out in spring 2006 (113 colonies) and 2010 (115 colonies: Fig. 1). Each sample contained about 150 adult inner worker honey bees from each colony. An etiological analysis was performed for some of the major pathogenic agents affecting honey bees, and subsequently, one adult worker honey bee from each colony was placed directly into $100 \%$ ethanol and stored at $-20{ }^{\circ} \mathrm{C}$ for later DNA analysis (Department of Zoology and Anthropology, Faculty of Veterinary Medicine, University of Murcia). The evolutionary lineage of each colony was determined previously by analyzing the mitochondrial DNA variation (Jara et al. 2012).

\section{DNA extraction and microsatellite analysis}

The two left legs were removed from one worker honey bee per colony, and the total DNA was extracted in a $5 \%$ Chelex solution according to a modified version of the protocol published by Walsh et al. (1991). The final solution of DNA $(2 \mu \mathrm{l})$ was then used for PCR amplification, performing two multiplex PCR reactions in order to study a total of 12 microsatellite loci in the genotype of the worker honey bees (Chahbar et al. 2013; Evans et al. 2013). PCR products were visualized by capillary electrophoresis (ABI-3730, Applied Biosystems) and sized with an internal standard (Servei Central de Suport 
Fig. 1 Map showing the location of the Apis mellifera iberiensis colonies sampled in 2006 and 2010 (from Jara et al. 2012)

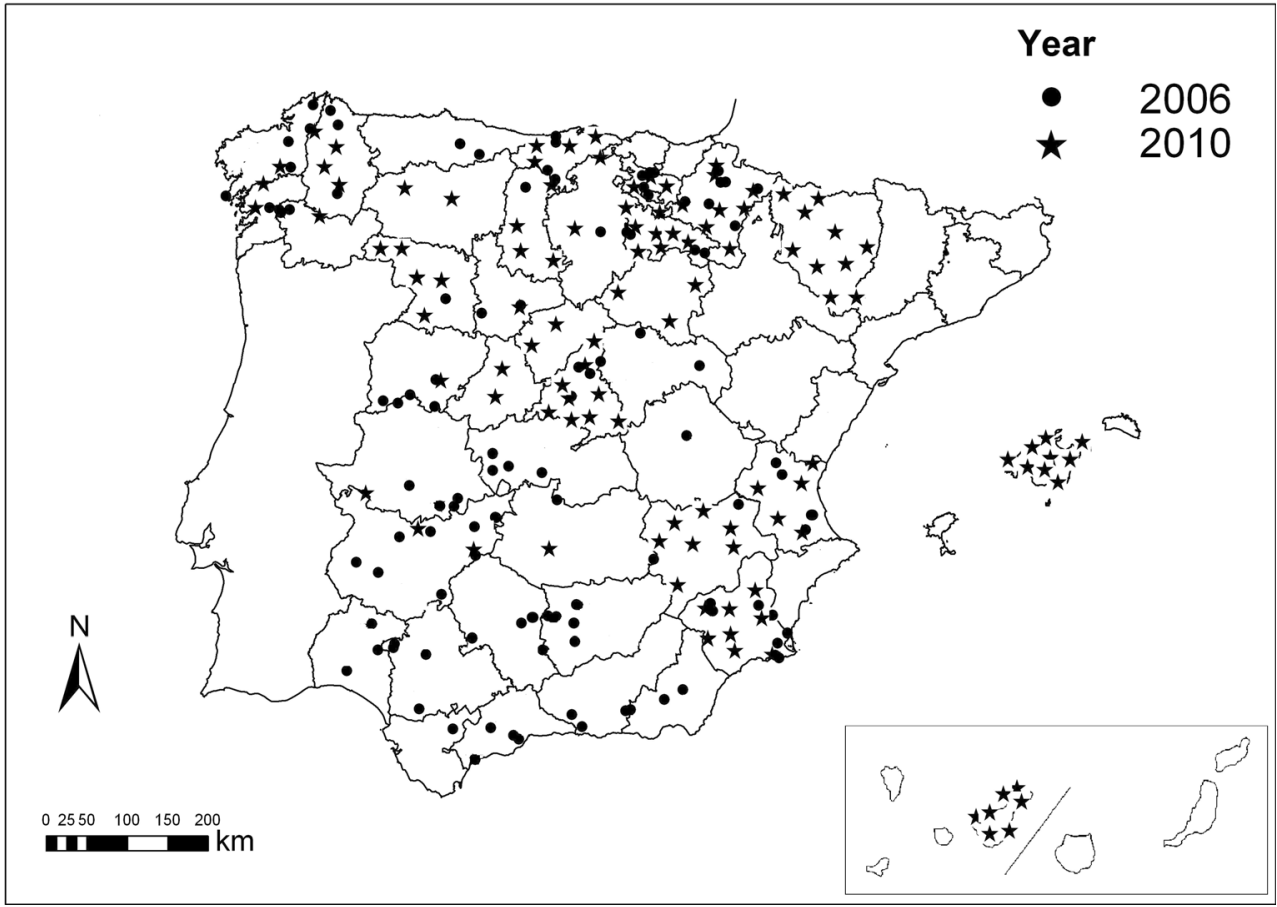

a la Investigació Experimental, University of Valencia, Spain). The individual alleles were subsequently scored using GeneMapper v3.7 software (Applied Biosystems).

\section{Detection of pathogenic agents}

All the samples came from colonies treated against Varroa (mandatory in the Spanish beekeeping regulation); therefore, the finding of Varroa-positive samples indicates that the treatment was not successful or incorrectly applied ( $>50 \%$ of the treatments are applied improperly in Spain: see Garrido Bailón 2012). Conversely, Varroa-negative colonies indicate either the result of a recent treatment (reducing infestation to levels below the threshold of detection) or the development of natural tolerance to Varroa as that reported by other authors (Rinderer et al. 2001; Büchler et al. 2002, 2008; Le Conte et al. 2007; Seeley 2007; Rosenkranz et al. 2010; Locke et al. 2012).

Nosema spp. and $V$. destructor presence had already been analyzed in these colonies (Jara et al. 2012). Briefly, about 150 inner worker honey bees from each colony were pooled and analyzed to detect the presence of Nosema spp. and $V$. destructor according to OIE recommendations (2008). To assay Nosema species, DNA extraction and PCR reactions were performed as described previously, using an internal PCR control to determine the reliability of the analysis (Martín-Hernández et al. 2007; Botías et al. 2011). Therefore, Nosema spp.- and $V$. destructor-negative colonies are defined here as colonies in which none of these parasites were detected in a sample of 150 bees.

\section{Genetic and statistical analysis}

Population genetic parameters were calculated for the samples in the two samplings (2006 and 2010) using GenAlex (Peakall and Smouse 2006). Given the notable genetic homogeneity found in the microsatellite analyses of Iberian honey bees across the Peninsula (Cánovas et al. 2011), we considered that all samples collected in the same year make up a single population. Genetic diversity was evaluated by calculating allele frequencies, comparing the observed $\left(H_{\mathrm{o}}\right)$ and expected $\left(H_{\mathrm{e}}\right)$ heterozygosity values. Population genetic differentiation was tested using Genepop software (Raymond and Rousset 1995; Rousset 2008), and the relationship between genetic diversity in the population and the prevalence of the pathogenic elements ( $V$. destructor and Nosema spp.) was analyzed with the Pearson's chi-squared and Fisher exact tests, as implemented in SPSS 19 for Windows.

\section{Detecting loci under selection}

To investigate whether selection affected any of the loci analyzed, we used the Lositan software (Antao et al. 2008). Adaptive differentiation has traditionally been identified from the differences in allele frequencies among different populations, summarized by an estimate of the $F_{\mathrm{ST}}$ (Beaumont 2005). Low-frequency outliers relative to an appropriate 
neutral population genetic model indicate loci subject to balancing selection, whereas high-frequency outliers suggest adaptive (directional) selection. Lositan is based on a method that describes the expected distribution of allele frequencies $\left(F_{\mathrm{ST}}\right)$ vs $H_{\mathrm{e}}$ under an island model of migration with neutral markers (Wright 1931). This distribution is used to identify outlier loci that have excessively high or low $F_{\mathrm{ST}}$ scores compared to neutral expectations. Such outlier loci are therefore candidates to be subject to selection.

To minimize the bias on the estimation of the mean neutral $F_{\mathrm{ST}}$, Lositan was run using all loci through 50,000 simulations. After the first run, those loci that appeared outside the desired confidence intervals (95\% CIs) were removed and the mean neutral $F_{\mathrm{ST}}$ was computed again. In this way, a more accurate estimate of the neutral $F_{\mathrm{ST}}$ value was obtained using only neutral loci. This refined estimate was used for a final set of 50,000 simulations over all loci, and the estimated selection status of each of them was reported.

The outlier loci were submitted to a sequence similarity search using Blast (www.ncbi.nlm.nih.gov) and BeeBase (http:/hymenopteragenome.org/beebase/), and likewise, they were screened for annotation of genes using the Map Viewer tool (NCBI; Amel 4.5). As the functional annotation of the honey bee genome is incomplete, putative Gene Ontology classifications were ascribed to genes based on homology to Drosophila melanogaster FlyBase (www.flybase.org), complemented by NCBI annotation.

\section{Results}

Of the 12 microsatellite loci analyzed, one (AC011) was removed from the analysis due to the poor efficiency of amplification and posterior fragment detection. For the 11 remaining microsatellite loci, we found a total of 122 different alleles within the 228 samples studied (Table 1). All the loci were polymorphic in both the 2006 and 2010 samplings, and the allele frequencies for all of them are listed in Supplementary material, including the observed $\left(H_{\mathrm{o}}\right)$ and expected $\left(H_{\mathrm{e}}\right)$ heterozygosity values.

There was allelic loss at the Ap43 and Ap55 loci in 2010 compared to 2006, and whereas five loci exhibited an increase (A8, Ap274, A79, A88, and Ap249), the remaining four maintained the same number of alleles in both samplings (A113, A7, B124, and Ap224). Of the 87 alleles identified in 2006, only 63 were found in samples collected in 2010, a loss of 24 alleles all of which had a low frequency (below 0.015). Moreover, of the 98 alleles recorded in 2010, 35 corresponded to alleles not detected in 2006, and again, these were alleles with a low frequency (between 0.005 and 0.018 ).

Highly significant genetic differentiation was found between 2006 and 2010, as evident with the G test implemented
Table 1 Microsatellite descriptive statistics for 2006 and 2010 samples of Apis mellifera iberiensis

\begin{tabular}{|c|c|c|c|c|c|c|}
\hline \multirow[t]{2}{*}{ Locus } & \multicolumn{2}{|l|}{$\mathrm{Na}$} & \multicolumn{2}{|l|}{$H_{\mathrm{o}}$} & \multicolumn{2}{|l|}{$H_{\mathrm{e}}$} \\
\hline & 2006 & 2010 & 2006 & 2010 & 2006 & 2010 \\
\hline A113 & 13 & 13 & 0.604 & 0.588 & 0.592 & 0.619 \\
\hline A7 & 7 & 7 & 0.459 & 0.330 & 0.478 & 0.416 \\
\hline Ap43 & 16 & 14 & 0.735 & 0.489 & 0.719 & 0.669 \\
\hline Ap55 & 12 & 11 & 0.673 & 0.689 & 0.744 & 0.755 \\
\hline B124 & 11 & 11 & 0.815 & 0.806 & 0.834 & 0.821 \\
\hline A79 & 9 & 11 & 0.146 & 0.194 & 0.294 & 0.301 \\
\hline A8 & 3 & 7 & 0.062 & 0.172 & 0.145 & 0.278 \\
\hline A88 & 3 & 7 & 0.081 & 0.400 & 0.132 & 0.363 \\
\hline Ap224 & 6 & 6 & 0.545 & 0.578 & 0.614 & 0.631 \\
\hline Ap249 & 2 & 5 & 0.033 & 0.058 & 0.464 & 0.122 \\
\hline Ap274 & 5 & 6 & 0.042 & 0.051 & 0.081 & 0.108 \\
\hline $\mathrm{All}^{\mathrm{a}}$ & 7.9 & 8.9 & 0.381 & 0.396 & 0.463 & 0.462 \\
\hline
\end{tabular}

Columns indicate the total number of alleles observed $(\mathrm{Na})$, observed heterozygosity $\left(H_{\mathrm{o}}\right)$, and expected heterozygosity $\left(H_{\mathrm{e}}\right)$ estimates per locus

${ }^{\text {a }}$ Average values across loci

in the Genepop software $(p<0.001)$. However, genetic diversity levels $\left(H_{\mathrm{e}}\right)$ were similar in both surveys $\left(H_{\mathrm{e}}\right.$ in $2006=$ $0.463 \pm 0.080$ and $0.462 \pm 0.075$ in 2010). These values are within the expected range of genetic diversity for $A . m$. iberiensis (Cánovas et al. 2011).

Of the 228 colonies randomly sampled in 2006 and 2010, at least one of the pathogenic agents analyzed was detected in almost $80 \%$ of them (V. destructor, N. apis, and N. ceranae), although they were less prevalent in 2006 (74 \%) than in 2010 $(83 \%)$. About $31 \%$ of the colonies analyzed in 2006 were parasitized by $V$. destructor, which decreased to $19 \%$ in 2010 (Table 2), while Nosema microsporidia were more prevalent than the V. destructor mite in $2006(64 \%)$ and 2010 (72\%). In $2006, N$. ceranae was detected in $50 \%$ of the colonies while $N$. apis was less frequent (13\%). However, by 2010, the presence of $N$. ceranae reached to $59 \%$, whereas in only three of the colonies sampled in 2010, N. apis was detected alone (3\%). Indeed, while $N$. apis and $N$. ceranae were detected together in only $1 \%$ of the colonies in 2006 , this had risen to $10 \%$ in 2010 (Table 2).

Since the genetic diversity of the A. m. iberiensis population was similar in 2006 and 2010, no temporal correlation could be established between this parameter and the prevalence of pathogens and parasites in the Iberian honey bee. Nevertheless, we analyzed the allelic patterns in the colonies parasitized by Varroa or Nosema separately vs Nosemal Varroa-negative colonies (i.e., without any of these pathogenic agents). Greater genetic diversity was found in these Nosema/Varroa-negative colonies $\left(H_{\mathrm{e}}=0.480 \pm 0.075\right)$ than 
Table 2 Presence of Nosema spp. and Varroa destructor by sampling year in Apis mellifera iberiensis colonies

\begin{tabular}{|c|c|c|}
\hline & \multicolumn{2}{|c|}{$\%$ Positive colonies (number of positive colonies) } \\
\hline & $2006(N=113)$ & $2010(N=115)$ \\
\hline N. ceranae & $50 \%(56)$ & $59 \%(68)$ \\
\hline N. apis & $13 \%(15)$ & $3 \%(3)$ \\
\hline Co-infection by $N$. apis $+N$. ceranae & $1 \%(1)$ & $10 \%(12)$ \\
\hline Total prevalence of Nosema spp. & $64 \%(72)$ & $72 \%(83)$ \\
\hline Prevalence of Varroa mite & $31 \%(35)$ & $19 \% \%^{\mathrm{a}}(21)$ \\
\hline Presence of at least one of the analyzed agents & $74 \%(84)$ & $83 \%(95)$ \\
\hline
\end{tabular}

${ }^{a}$ Varroa presence was not analyzed in six of the 115 colonies from the sampling in 2010. Furthermore, the percentage is calculated in this case based on 109 colonies analyzed in the parasitized colonies $\left(H_{\mathrm{e}}=0.464 \pm 0.075\right)$, and although these differences did not appear to be statistically significant (Student $t=-0.149, p=0.441$ ), the $\mathrm{G}$ test revealed highly significant genetic differentiation between these two groups of colonies $(p<0.001)$.

To further analyze these genetic differences, we studied the allele frequency patterns of each locus in colonies sampled in 2006 vs colonies sampled in 2010. Coalescent simulations performed with Lositan software detected an outlier locus (Ap249) as a candidate of being subjected to positive selection (Table 3). The comparison between Nosemal Varroa-negative colonies vs colonies parasitized by Varroa revealed another outlier locus, B124, as a candidate for positive directional selection (Table 4). No outliers were detected when comparing Nosema/Varroa-negative colonies vs positive colonies to Nosema spp., irrespective of the sampling year. Screening for annotated genes (Map Viewer tool NCBI; Amel 4.5) showed that the Ap249 locus is located on chromosome LG2 of A. mellifera and that it is linked to the protein-coding gene Aos 1 related to protein degradation,

Table 3 Results of the outlier analysis of Apis mellifera iberiensis populations when comparing 2006 and 2010 samples

\begin{tabular}{llll}
\hline Locus & $H_{\mathrm{e}}$ & \multicolumn{1}{l}{$F_{\mathrm{ST}}$} & $P\left(\operatorname{Simul} F_{\mathrm{ST}}<\right.$ sample $\left.F_{\mathrm{ST}}\right)$ \\
\hline A113 & 0.606836 & -0.003254 & 0.33287 \\
A7 & 0.450309 & 0.002717 & 0.475918 \\
Ap43 & 0.703883 & 0.008342 & 0.464157 \\
Ap55 & 0.789031 & 0.045271 & 0.824397 \\
B124 & 0.829635 & -0.003618 & 0.142272 \\
A79 & 0.29875 & -0.002601 & 0.450995 \\
A8 & 0.216294 & 0.017493 & 0.593753 \\
A88 & 0.267323 & 0.069342 & 0.869986 \\
Ap224 & 0.623494 & -0.00542 & 0.30051 \\
Ap249 & 0.39438 & 0.250268 & 0.999406 \\
Ap274 & 0.094999 & -0.001697 & 0.386087
\end{tabular}

Locus Ap249 shows a high probability of being subjected to selective pressures whereas B124 locus is located on chromosome LG13 and it is associated with the $d p r 7$ gene that encodes immunoglobulin proteins.

\section{Discussion}

This study indicates that the genetic diversity level among honey bee colonies in Spain has remained stable over the last decade, despite the colony losses recorded in this and other European countries (Higes et al. 2010a, b; vanEngelsdorp and Meixner 2010). Therefore, the initial hypothesis that the increased incidence of parasites $(V$. destructor) and pathogens (N. apis and N. ceranae) in recent years was associated with a decrease in genetic diversity of the Iberian honey bee population was not corroborated here. This result does not rule out the possibility of such effects at a local or intra-colony scale, an issue that deserves more specific research. However, the genetic diversity levels at the peninsular scale $\left(H_{\mathrm{e}}\right)$ remained similar in both years surveyed, $2006\left(H_{\mathrm{e}}=0.463 \pm 0.080\right)$ and

Table 4 Results of the outlier analysis when comparing Apis mellifera iberiensis populations (2006 plus 2010 samples) negative for Varroa/ Nosema infestation vs colonies parasitized by $V$. destructor

\begin{tabular}{llll}
\hline Locus & $H_{\mathrm{e}}$ & $F_{\mathrm{ST}}$ & $\mathrm{P}\left(\operatorname{Simul} F_{\mathrm{ST}}<\right.$ sample $\left.F_{\mathrm{ST}}\right)$ \\
\hline A113 & 0.62406 & -0.000357 & 0.613779 \\
A7 & 0.478716 & $2.8 \mathrm{e}-05$ & 0.69447 \\
Ap43 & 0.681419 & -0.007087 & 0.436818 \\
Ap55 & 0.791319 & 0.001775 & 0.562544 \\
B124 & 0.866319 & 0.047409 & 0.985782 \\
A79 & 0.401316 & 0.021712 & 0.798066 \\
A8 & 0.336097 & 0.029368 & 0.85626 \\
A88 & 0.201974 & -0.008837 & 0.470685 \\
Ap224 & 0.648352 & -0.00876 & 0.437697 \\
Ap249 & 0.357919 & 0.025789 & 0.829389 \\
Ap274 & 0.077703 & -0.000715 & 0.595662
\end{tabular}

Locus B124 shows a high probability of being subjected to selective pressures 
$2010\left(H_{\mathrm{e}}=0.462 \pm 0.075\right)$. In fact, the genetic diversity recorded in this study is concordant with that obtained previously in the Iberian Peninsula studying microsatellite loci (Cánovas et al. 2011: $H_{\mathrm{e}} 0.401$ to 0.518; Miguel et al. 2007: $H_{\mathrm{e}} 0.442$ to 0.516 ). As discussed by these authors, honey bee populations in Spain might be considered to make up a single large population for certain purposes, given the large population interchange and gene flow derived from the extensive beekeeping mobility around the Peninsula (Cánovas et al. 2011; 2014). In fact, around $80 \%$ of the estimated number of Spanish colonies move in a yearly cycle, which leads to a potential bi-directional genetic flow between migratory and resident colonies (Perrier et al. 2003; Hernández-García 2010), an effect that is enhanced by the lack of control that beekeepers have on natural honey bee mating (Baudry et al. 1998; Koeniger and Koeniger 2000; Hernández-García et al. 2009; Jaffé et al. 2009). Additional factors promoting the genetic homogeneity in the Iberian Peninsula are the capture of swarms and the purchase of colonies or mated queens, often originating from distant locations (Cánovas et al. 2008; Serrano et al. 2011). All these factors would account for the maintenance of genetic diversity in Iberian honey bee populations reported in this study, despite of the colony losses occurred in recent decades. However, there is an evident risk of disease spreading as a result of the intense colony movement between most regions in the Iberian Peninsula. In this sense, the increased prevalence of pathogens in Spain during the study period is not surprising, consistent with data found in other studies (Higes et al. 2010a, b; Botías et al. 2012; Martín-Hernández et al. 2012; Muñoz et al. 2014) and in other regions (Fries 2010; Traver and Fell 2011; Martin et al. 2013; Bekele et al. 2015). It is noteworthy that around $74 \%$ (2006) or $86 \%$ (2010) of the colonies presented at least one of the searched pathogenic agents $(V$. destructor, $N$. apis, and $N$. ceranae) showing $N$. apis a lower prevalence even though the samples were obtained in Spring, the peak season for N. apis infestation (Fries 2010). By contrast, $N$. ceranae was the pathogen that showed the greatest expansion with an increase in prevalence of $10 \%$ in the 4 years of our study. This high prevalence of parasites and pathogens, and the fast expansion of $N$. ceranae, are of particular concern given the potential of $V$. destructor (Rosenkranz et al. 2010) and N. ceranae (Martín-Hernández et al. 2007; Higes et al. 2008) to produce colony collapse.

A relationship between honey bee genetic diversity and the prevalence of parasites and pathogens could not be established in this study due to the genetic stability observed. However, we did detect significant genetic differences in the surveys performed in 2006 and 2010 (G test, $p<0.001$ ), as well as Varroa/Nosema-negative colonies and parasitized colonies ( $\mathrm{G}$ test, $p<0.001$ ), with tentatively higher $H_{\mathrm{e}}$ values in the Varroa/Nosema-negative colonies compared to parasitized ones. This is consistent with studies showing that colonies of genetically diverse social insects have a selective advantage because of increased resistance to pests (Sherman et al. 1988; Liersch and Schmid-Hempel 1998; Tarpy 2003; vanBaalen and Beekman 2006; Mattila and Seeley 2007; Oldroyd and Fewell 2007). It is thought that different host genotypes have distinct susceptibilities to diverse parasitic strains; thus, parasitic infections are not likely to spread in genetically heterogeneous colonies as rapidly as in more homogeneous ones (Sherman et al. 1988; Schmid-Hempel 1998). Studies on different Hymenoptera species also support this hypothesis, including those on bumblebees like Bombus terrestris (Liersch and Schmid-Hempel 1998; Baer and Schmid-Hempel 2001) and Bombus pascuorum (Whitehorn et al. 2011) and on ants (Hughes and Boomsma 2004).

To further investigate the genetic differences between the groups of colonies, we studied whether any of the loci analyzed was subject to selective pressure. A comparison of allele frequencies between the samples collected in 2006 and 2010 showed that the Ap249 locus was subjected to positive selection during that period. Searches of the complete A. mellifera genome (Consortium HGS 2006) showed that this locus is located on the chromosome LG2 and that it is linked to the protein-coding gene Aos 1 . Experimental data in D. melanogaster indicate that Aos 1 (FlyBase: http://flybase. org/reports/FBgn0029512.html, 16/01/2015) is involved in the biological processes of protein sumoylation, a protein modification implicated in various cellular processes that include the stress response (Hay 2005; Paddibhatla et al. 2010), and the positive regulation of the NF-kappaB transcription factor, a modulator of the immune response to infection and of nervous system plasticity (Ghosh et al. 1998; Albensi and Mattson 2000; Li and Verma 2002; Meffert et al. 2003).

When comparing Varroa/Nosema-negative colonies vs colonies parasitized by $V$. destructor, we found a second outlier locus, B124. As noted before, Varroa-negative colonies might be false negatives because of a recent treatment, but also the result of the development of natural tolerance to the mite. It is interesting that the screening of B124 in the annotated genome of A. mellifera (Map Viewer tool, NCBI; Amel 4.5) suggested the linkage of this locus with the $d p r 7$ gene that encodes immunoglobulin proteins (FlyBase: http://flybase.org/ reports/FBgn0053481.html, 16/01/2015).

In conclusion, in this study, we show that the genetic diversity in Spanish honey bee populations remained stable between 2006 and 2010, despite the increasing levels of pathogens and parasites. This result possibly reflects the multidrone mating system of the queens and the high gene flow between colonies over most regions of the country. We identify two outlier loci related to genes that respond to stress and that could potentially reflect selective processes a hypothesis that should be assessed in more specific analyses. 
Acknowledgments We thank beekeepers for providing the samples analyzed. This study was supported by INIA-FEDER grant numbers RTA2013-00042-C10-05 and 06 and RTA2008-00020-C02. The corresponding author of this paper is presently a member and receive support from COST Action FA1307 (Sustainable pollination in Europe: joint research on bees and other pollinators (SUPER-B). Irene Muñoz is supported by Fundación Séneca (Murcia, Spain) through the post-doctoral fellowship 19149/PD/13-N. We very much appreciated the helpful comments to improve the manuscript of two anonymous reviewers and the Editor Sven Thatje.

\section{References}

Albensi BC, Mattson MP (2000) Evidence for the involvement of TNF and NF-kappaB in hippocampal synaptic plasticity. Synapse 35: $151-159$

Anderson DL, Trueman JWH (2000) Varroa jacobsoni (Acari: Varroidae) is more than one species. Exp Appl Acarol 24:165-189

Antao T, Lopes A, Lopes R, Beja-Pereira A, Luikart G (2008) LOSITAN: a workbench to detect molecular adaptation based on a Fst-outlier method. BMC Bioinformatics 9:323-327

Baer B, Schmid-Hempel P (2001) Unexpected consequences of polyandry for parasitism and fitness in the bumblebee, Bombus terrestris. Evolution 55:1639-1643

Baudry E, Solignac M, Garnery L, Gries M, Cornuet JM, Koeniger N (1998) Relatedness among honey bees (Apis mellifera) of a drone congregation area. Proc R Soc B 265:2009-2014

Beaumont MA (2005) Adaptation and speciation: what can Fst tell us? Trends Ecol Evol 20:435-440

Bekele AZ, Mor SK, Phelps NB, Goyal SM, Armién AG (2015) A case report of Nosema ceranae infection in honey bees in Minnesota, USA. Vet Q 35:48-50

Biesmeijer JC, Roberts SPM et al (2006) Parallel declines in pollinators and insect-pollinated plants in Britain and the Netherlands. Science 313:351-354

Botías C, Martín-Hernández R, Meana A, Higes M (2011) Critical aspects of the Nosema spp. diagnostic sampling in honey bee (Apis mellifera L.) colonies. Parasitol Res 110:2557-2561

Botías C, Martín-Hernández R, Garrido-Bailón E, González-Porto A, Martínez-Salvador A, De la Rúa P, Meana A, Higes M (2012) The growing prevalence of Nosema ceranae in honey bees in Spain, an emerging problem for the last decade. Res Vet Sci 93:150-155. doi: 10.1016/j.rvsc.2011.08.002

Büchler R, Berg S, Kezic N, Pechhacker H, vanPraagh J, Bubalo D, Ritter W, Bienefeld K (2002) Survival test without treatment against varroatosis - the island project in Croatia. Apidologie 33:493-494

Büchler R, Garrido C, Bienefeld K, Ehrhardt K (2008) Selection for Varroa tolerance: concept and results of a long-term selection project. Apidologie 39:598

Cánovas F, De la Rúa P, Serrano J, Galián J (2008) Geographic patterns of mitochondrial DNA variation in Apis mellifera iberiensis (Hymenoptera: Apidae). J Zool Syst Evol Res 46:24-30

Cánovas F, De la Rúa P, Serrano J, Galián J (2011) Microsatellite variability reveals beekeeping influences on Iberian honey bee populations. Apidologie 3:235-251

Cánovas F, De la Rúa P, Serrano J, Galián J (2014) Analysis of a contact area between two distinct evolutionary honeybee units: an ecological perspective. J Insect Conserv 18:927-937

Chahbar N, Muñoz I, Dall'Olio R, De la Rúa P, Serrano J, Sallaheddine D (2013) Population structure of North African honey bees is influenced by both biological and anthropogenic factors. J Insect Conserv 17:385-392
Chen Y, Evans JD (2007) Historical presence of Israeli Acute Paralysis Virus in the United States. Am Bee J 147:1027-1028

Consortium HGS (2006) Insights into social insects from the genome of the honey bee Apis mellifera. Nature 443:931-949

Cox-Foster DL, Conlan S, Holmes EC et al (2007) A metagenomic survey of microbes in honey bee colony collapse disorder. Science 318: 283-286

Crozier RH, Fjerdingstad EJ (2001) Polyandry in social Hymenopteradisunity in diversity? Ann Zool Fenn 38:267-285

Crozier RH, Page RE (1985) On being the right size - male contributions and multiple mating in social Hymenoptera. Behav Ecol Sociobiol 18:105-115

De la Rúa P, Jaffé R, Muñoz I, Serrano J, Moritz RFA, Kraus FB (2013) Conserving genetic diversity in the honey bee. Comments on Harpur et al. (2012). Mol Ecol 22:3208-3210

de Miranda JR, Genersch E (2010) Deformed wing virus. J Invertebr Pathol 103:S48-S61

de Miranda JR, Cordoni G, Budge G (2010) The acute bee paralysis virus - Kashmir bee virus-Israeli paralysis virus complex. J Invertebr Pathol 103:S30-S47

Evans JD, Schwarz RS, Chen YP et al (2013) Standard methodologies for molecular research in Apis mellifera. In Dietemann V, Ellis JD, Neumann P (ed) The COLOSS BEEBOOK, volume I: standard methods for Apis mellifera research. J Apicult Res. doi:10.3896/ IBRA.1.52.4.11

Frankham R, Ballou JD, Briscoe DA (2010) Introduction to conservation genetics. Cambridge University Press, Cambridge

Fries I (2010) Nosema ceranae in European honey bees (Apis mellifera). J Invertebr Pathol 103:S73-S79

Garrido Bailón E (2012) Repercusión potencial en la cabaña apícola española de agentes nosógenos detectados en colonias de Apis mellifera iberiensis, $\mathrm{PhD}$ Dissertation. Universidad Complutense de Madrid, Spain

Ghosh S, May MJ, Kopp EB (1998) NF-кB and Rel proteins: evolutionarily conserved mediators of immune responses. Annu Rev Immunol 16:225-260

Harpur BA, Minaei S, Kent CF, Zayed A (2012) Management increases genetic diversity of honey bees via admixture. Mol Ecol 21:44144421

Hay RT (2005) SUMO: a history of modification. Mol Cell 18:1-12

Hernández-García R (2010) Caracterización molecular y estudio biométrico de poblaciones estantes y trashumantes de Apis mellifera iberiensis(Engel 1999). PhD Dissertation, University of Murcia

Hernández-García R, De la Rúa P, Serrano J (2009) Mating frequency of Apis mellifera iberiensis queens. J Apicult Res Bee World 48:121125

Higes M, Martin R, Meana A (2006) Nosema ceranae, a new microsporidian parasite in honey bees in Europe. J Invert Pathol 92:93-95

Higes M, Martín-Hernandez R, Botias C, Bailón EG, Gonzales-Porto A, Barrios L, Del Nozal MJ, Palencia PG, Meana A (2008) How natural infection by Nosema ceranae causes honey bee colony collapse. Environ Microbiol 10:2659-2669

Higes M, Martín-Hernández R, Martínez-Salvador A, Garrido-Bailón E, González-Porto AV, Meana A, Bernal JL, del Nozal MJ, Bernal J (2010a) A preliminary study of the epidemiological factors related to honey bee colony loss in Spain. Environ Microbiol Rep 2:243-250

Higes M, Martín-Hernández R, Meana A (2010b) Nosema ceranae in Europe: an emergent type C nosemosis. Apidologie 41:375-392

Hughes WHO, Boomsma JJ (2004) Genetic diversity and disease resistance in leaf-cutting ant societies. Evolution 58:1251-1260

Jaffé R, Dietemann V, Crewe RM, Moritz RFA (2009) Temporal variation in the genetic structure of a drone congregation area: an insight into the population dynamics of wild African honeybees (Apis mellifera scutellata). Mol Ecol 18:1511-1522 
Jara L, Cepero A, Garrido-Bailón E, Martín-Hernández R, Higes M, De la Rúa P (2012) Linking evolutionary lineage with parasite and pathogen prevalence in the Iberian honey bee. J Invertebr Pathol 110:813

Johnson RM, Pollock HS, Berenbaum MR (2009) Synergistic interactions between in-hive miticides in Apis mellifera. J Econ Entomol 102:474-479

Koeniger N, Koeniger G (2000) Reproductive isolation among species of the genus Apis. Apidologie 31:313-339

Le Conte Y, de Vaublanca G, Crausera D, Jeanneb F, Roussellec J-C, Bécarda J-M (2007) Honey bee colonies that have survived Varroa destructor. Apidologie 38:566-572

Li Q, Verma IM (2002) NF-kappaB regulation in the immune system. Nat Rev Immunol 2:725-734

Liersch S, Schmid-Hempel P (1998) Genetic variation within social insect colonies reduces parasite load. Proc R Soc Lond B 265:221225

Locke B, Forsgren E, Fries I, de Miranda J (2012) Acaricide treatment affects viral dynamics in varroa destructor-infested honey bee colonies via both host physiology and mite control. Appl Environ Microbiol 78:227-235

Martin SJ, Hardy J, Villalobos E, Martín-Hernández R, Nikaido S, Higes M (2013) Do the honeybee pathogens Nosema ceranae and deformed wing virus act synergistically? Environ Microbiol Rep 5: 506-510

Martín-Hernández R, Meana A, Prieto L, Martínez-Salvador A, GarridoBailón E, Higes M (2007) Outcome of colonization of Apis mellifera by Nosema ceranae. Appl Environ Microbiol 73:6331-6338

Martín-Hernández R, Botías C, Bailón EG, Martínez-Salvador A, Prieto L, Meana A, Higes M (2012) Microsporidia infecting Apis mellifera: coexistence or competition. Is Nosema ceranae replacing Nosema apis? Environ Microbiol 14:2127-2138

Martinson VG, Danforth BN, Minckley RL, Rueppell O, Tingek S, Morgan N (2011) Simple and distinctive microbiota associated with honey bees and bumble bees. Mol Ecol 20:619-628

Mattila HR, Seeley TD (2007) Genetic diversity in honey bee colonies enhances productivity and fitness. Science 317:362-364

McNeely JA, Miller KR, Reid WV, Mittermeier RA, Werner TB (1990) Conserving the World's Biological Diversity. IUCN, World Resources Institute, Conservation International, WWF-US and the World Bank, Washington DC

Meffert MK, Chang JM, Wiltgen BJ, Fanselow MS, Baltimore D (2003) NF-kappa B functions in synaptic signaling and behavior. Nat Neurosci 6:1072-1078

Miguel I, Iriondo M, Garnery L, Sheppard WS, Estonba A (2007) Gene flow within the M evolutionary lineage of Apis mellifera: role of the Pyrenees, isolation by distance and post-glacial recolonization routes in the Western Europe. Apidologie 38:141-155

Muñoz I, Pinto MA, De la Rúa P (2013) Temporal changes in mitochondrial diversity highlights contrasting population events in Macaronesian honey bees. Apidologie 44:295-305

Muñoz I, Cepero A, Pinto MA, Martín-Hernández R, Higes M, De la Rúa P (2014) Presence of Nosema ceranae associated with honeybee queen introductions. Infect Genet Evol 23:161-168

OIE: Office International des Épizooties (2008) Manual of Standards for Diagnostic Test and Vaccines. http://www.oie.int/doc/ged/D7710. pdf. Accessed 11 Feb 2015

Oldroyd BP, Fewell JH (2007) Genetic diversity promotes homeostasis in insect colonies. Trends Ecol Evol 22:408-413

Oxley PR, Oldroyd BP (2010) The genetic architecture of honey bee breeding. Adv Insect Physiol 39:83-118

Paddibhatla I, Lee MJ, Kalamarz ME, Ferrarese R, Govind S (2010) Role for sumoylation in systemic inflammation and immune homeostasis in Drosophila larvae. PLoS Pathog 6, e1001234

Palmer KA, Oldroyd BP (2000) Evolution of multiple mating in the genus Apis. Apidologie 31:235-248
Peakall R, Smouse PE (2006) GENALEX 6: genetic analysis in Excel. Population genetic software for teaching and research. Mol Ecol Notes 6:288-295

Perrier C, Strange J, Langella O, Sheppard WS, Garnery L (2003) Diversité génétique, introgressions mitochondriales et nucléaires dans une population d'abeilles des Landes de Gascogne. Actes BRG 4:79-100

Raymond M, Rousset F (1995) GENEPOP (version 1.2): population genetics software for exact tests and ecumenicism. J Hered 86 : 248-249

Reed DH, Frankham R (2003) Correlation between fitness and genetic diversity. Conserv Biol 17:230-237

Rinderer TE, De Guzman LI, Delatte GT, Stelzer JA, Lancaster VA, Kuznetsov V, Beaman L, Watts R, Harris JW (2001) Resistance to the parasitic mite Varroa destructor in honeybees from far eastern Russia. Apidologie 31:381-394

Rosenkranz P, Aumeier P, Ziegelmann B (2010) Biology and control of Varroa destructor. J Invertebr Pathol 103:S96-S119

Rousset F (2008) Genepop'007: a complete reimplementation of the Genepop software for Windows and Linux. Mol Ecol Resour 8: 103-106

Rueppell O, Hayes AM, Warrit N, Smith DR (2011) Population structure of Apis cerana in Thailand reflects biogeography and current gene flow rather than Varroa mite association. Insect Soc 58:445-452

Schmid-Hempel P (1998) Parasites in social insects. Princeton University Press, Princeton

Seal US (1991) Disease and captive conservation of threatened species. SSC Working Group meeting of the National Zoo, Washington DC

Seeley TD (2007) Honeybees of the Arnot forest: a population of feral colonies persisting with Varroa destructor in the northeastern Unites States. Apidologie 38:19-29

Serrano J, Cánovas F, Hernández-García R, Galián J, De la Rúa P (2011) De África a Europa pasando por Iberia: Historia evolutiva de la abeja ibérica. In: Padilla-Álvarez F (ed) Actas del VI Congreso Nacional de Apicultura. Don Folio, Córdoba, pp 7-22

Sherman PW, Seeley TD, Reeve HK (1988) Parasites, pathogens, and polyandry in social Hymenoptera. Am Nat 131:602-610

Spielman D, Brook BW, Briscoe DA, Frankham R (2004) Does inbreeding and loss of genetic diversity decrease disease resistance? Conserv Genet 5:439-448

Tarpy DR (2003) Genetic diversity within honey bee colonies prevents severe infections and promotes colony growth. Proc R Soc Lond B 270:99-103

Traver BE, Fell RD (2011) Prevalence and infection intensity of Nosema in honey bee (Apis mellifera L.) colonies in Virginia. J Invertebr Pathol 107:43-49

vanBaalen M, Beekman M (2006) The costs and benefits of genetic heterogeneity in resistance against parasites in social insects. Am Nat 167:568-577

vanEngelsdorp D, Meixner MD (2010) A historical review of managed honey bee populations in Europe and the United States and the factors that may affect them. J Invertebr Pathol 103:80-95

vanEngelsdorp D, Evans JD, Saegerman C, Mullin C, Haubruge E, Nguyen BK, Frazier M, Frazier J, Cox-Foster D, Chen Y, Underwood R, Tarpy DR, Pettis JS (2009) Colony collapse disorder: a descriptive study. PLoS ONE 4, e6481

Walsh PS, Metzqer DA, Higuchi R (1991) Chelex 100 as a medium for simple extraction of DNA for PCR-based typing from forensic material. Biotechniques 10:506-512

Whitehorn PR, Tinsley MC, Brown MJF, Darvill B, Goulson D (2011) Genetic diversity, parasite prevalence and immunity in wild bumblebees. Proc R Soc Lond B 278:1195-1202

Wright S (1931) Evolution in Mendelian populations. Genetics 16:97159 